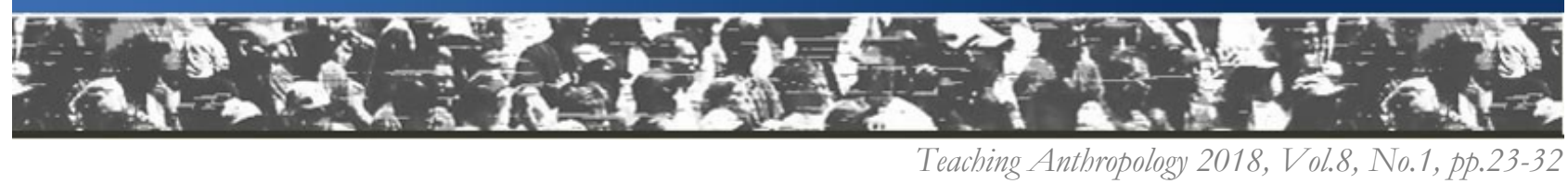

\title{
Convivio: Tolerance, Diversity, and Campus Identity During the Trump Era
}

\author{
Abigail Wightman \\ Mary Baldwin University
}

\begin{abstract}
In May 2017, twenty "student-artists" at Mary Baldwin University collaborated to create a mural about our institution and our very diverse student community. As a three week May Term course, the mural project continued a difficult conversation about diversity and inclusion on campus that occurred in the aftermath of Donald Trump's election as president of the United States. The purpose of this article is to discuss how ethnographic methods were used to develop mural themes, as well as to discuss the ways that the mural itself, and the process of its creation, reveal student anxieties about and responses to the policies and rhetoric of the Trump administration. Despite the very real threats to their own safety and that of their family and friends, student-artists challenged the inherent insecurity caused by administration policies through their insistence on inclusion, tolerance, and co-existence.
\end{abstract}

\section{Introduction}

In November 2016, exactly one week after the polls closed on the presidential election, students, faculty, and staff at Mary Baldwin University in Staunton, Virginia gathered for a community forum. Intended to quickly respond to the concerns of our diverse student population, the event was well-attended. Over the following two hours, students shared their feelings about the election. The stories that emerged reflected the anxiety that Donald Trump's election inflicted on diverse populations, especially communities of color and sexual and gender minorities. A trans student, through tears, related concerns over his rights and safety. A young African American woman was visibly upset as she told us about how police brutality might affect her young brother. Another student, similarly, couldn't continue speaking after relating that she was the victim of years of sexual abuse and felt re-traumatized by the election of an accused sexual predator. Many students spoke of fear for their undocumented family and friends. Some issues were local: students raised concerns about racism on campus and in the largely rural, white, conservative Shenandoah Valley. Yet even in the midst of the fear and anxiety, students overwhelmingly reaffirmed their support for one another and their goal of creating a truly inclusive campus community, a place of tolerance in the midst of rising racism, sexism, and xenophobia.

As part of this ongoing campus conversation around diversity and inclusion, in May 2017 twenty undergraduate students at Mary Baldwin University were tasked with creating a mural together that represented our campus community. The mural project was part of a four credit, interdisciplinary, three-week May Term course called "Permeable Borders," directed by artist-in-residence Claudia Bernardi and three artist colleagues, Rosa del Carmen Argueta de Ramos, Claudia Verenice Flores Escolero, and America Argentina Vaquerano Romero from the School of Art and Open Studio in Perquin, El Salvador. The result was a 30ft long, $6 \mathrm{ft}$ wide mural, titled "Convivio" by the student-artists. Through a vividly-colored backdrop of rivers, mountains, and a winding train, the student-artists charted the great changes and challenges of Mary Baldwin University in the context of our current era of anxieties and uncertainties. Amongst the images of campus buildings and other iconic aspects of Mary Baldwin, the student-artists represented conflict and fear as well as tolerance and hope for the future. Although the student-artists had some thematic and artistic direction, "Convivio" was their project and, as such, the mural is their collective representation of Mary Baldwin as well as a commentary on the state of the university and the wider world beyond our campus community.

Along with my co-instructor, art history professor Marlena Hobson, I worked, in particular, to help the studentartists develop mural themes prior to painting. As a cultural anthropologist, my role was to briefly introduce our student-artists to ethnographic methods so that they could better "study" Mary Baldwin University and, 
hopefully, produce a mural that included ideas, visions, and concerns of the larger student body. In this paper, I will focus on two main points: first, a discussion of the challenges of merging anthropology into an intentionally interdisciplinary and experiential course focused around the creation of a community art project and second, an analysis of the mural itself. As artist-in-residence Bernardi has written, murals are "books with no words" (2010, 84) and "Convivio" in particular is a fascinating window into student concerns during the uncertainty of the Trump era and their views of the campus community of which they are a part. The title itself, a term introduced to the class by Bernardi as a particularly Salvadoran concept of being together or co-existing, signals that the 2017 Permeable Borders mural intentionally critiques and unsettles the dominant xenophobia and racism of the Trump administration's rhetoric and policies. Simultaneously, "Convivio" emphatically, and perhaps aspirationally, proclaims Mary Baldwin University as a place of diversity and tolerance.

\section{Mural in Context}

Mary Baldwin University is a small, private, independent liberal arts university located in the Shenandoah Valley of Virginia, in the small town of Staunton. Although historically a women's residential college, the University began admitting non-residential men to undergraduate and graduate programs in the 1970s, though women continue to be a majority in all programs. In 2016-2017, 1,761 students were enrolled across two campuses and multiple regional centers. On the residential college on the historic Staunton campus, 656 were enrolled in Mary Baldwin College for Women. ${ }^{1}$ One of the most important aspects of the contemporary Mary Baldwin is, perhaps, our striking racial and ethnic diversity, which challenges common assumptions of women's colleges as a stronghold of elite white women. Mary Baldwin College for Women is particularly diverse; 2016 enrolment data indicated that $56 \%$ of students identified as non-white and 36\% of the incoming 2016 class were first generation students, with neither parent having any university education. ${ }^{2}$ Mary Baldwin College for Women also includes significant diversity in terms of gender identity, sexual orientation, and religious affiliation. The enrolment of the Permeable Borders course reflected this diversity. Enrolled students included women, one man, residential and commuter students, and a myriad of differences in terms of race, ethnicity, religion, gender identity, and sexual orientation.

What eventually became the Permeable Borders course began in 2006, when Argentine-born visual artist Claudia Bernardi came to Mary Baldwin University (then College) as a Doenges Scholar, a fellowship program which brings visiting scholars to our campus first in the fall semester and then in the spring to teach a three-week course May Term course. Bernardi was invited to Mary Baldwin because of her community art work creating murals with the survivors of violence in Central America. After Bernardi's successful first visit at Mary Baldwin, she has returned annually as a visiting artist and with my co-instructor, art history professor Marlena Hobson, developed an interdisciplinary class entitled Permeable Borders.

Bernardi's work as a community artist is, as she has written, intended to examine "the intersection of politics, ethics, and aesthetics" $(2010,82)$. Although she does not conceive of community mural projects as "art therapy" (85), she bases her work on the belief that "art will assist in the recovery of the suffering endured, which will be birthed as communal proposition" (82). As a result, Bernardi has developed a strategy for creating community art that she calls the "Perquin Model," named for the village in El Salvador where Bernardi created her first community mural. Bernardi defines the Perquin Model as a collaborative community art project that takes place in a community that has been the victim of political and/or physical violence, in which the participants "decide on the theme and narration of each piece with the intention to produce a visual testimony that represents their recent history" $(2010,82)$. Ideally, this process would have a legal impact, as the visual testimony is intended to be used in diplomacy, judicial concerns, and calls for human rights. The Perquin Model has been implemented in the creation of community art throughout El Salvador, as well as Guatemala, Colombia, Canada, Northern Ireland, Germany, Switzerland, Argentina and with the Yurok Tribe by the Klamath River in Northern California.

Bernardi also used the Perquin Model in the Permeable Borders course at Mary Baldwin University. Although the location and context varied widely - from Waynesboro, Virginia to Perquin, El Salvador - each course involved the creation of a mural with a local group or community. Mary Baldwin students helped to coordinate the creation of the mural, including developing mural themes and design elements with the local community.

1 Mary Baldwin University statistics provided by Carrie Boyd, Coordinator of Institutional Reporting and Research, based on the Mary Baldwin University Enrollment Report 2016-2017.

2 Students who identified as "non-white" were categorized as: 31\% Black; 12\% Hispanic; 13\% Other (Includes Asian, American Indian/Alaska Native, Native Hawaiian or other Pacific Islander, and 2 or more races). 
Most of these murals addressed serious issues such as poverty, racial segregation, migration, and many forms of violence. In 2013, for example, students and faculty worked with alumni of the former Booker T. Washington High School to create a mural that celebrated their community and reflected upon the experiences of segregation and integration in Staunton. For the last three years, Permeable Borders had been taught, and a mural created with, incarcerated youth - some of them unaccompanied minors - held at a secure juvenile detention center.

Although continuing many methods and themes, this year's mural was a departure in several ways. Instead of working with an external group or community, the mural organizers focused our project internally, at Mary Baldwin University. As mentioned above, this decision was directly linked to the post-election forum and our desire to address our students' uncertainties and fears. In spring 2017, MBU students continued to be highly attuned to the political climate and grew increasingly fearful and anxious. In casual conversations, advising sessions, and in class, students questioned their own and their family's security and safety. Like many other institutions ("A Rundown of the Latest Campus-Climate Incidents Since Trump's Election"), our campus experienced several racist incidents in the days following Trump's election: the appearance of a swastika on a dorm door and a student who was verbally attacked with racial slurs from a passing car while walking on a street at the edge of campus. While this was certainly not the same level of violence and trauma that are typical of Bernardi's community art in Central America, some MBU students felt, and likely continue to feel, threated with political violence as a result of Trump's election and ensuing policies.

The 2016 presidential election also coincided with significant changes to our Mary Baldwin community. In late November, the University administration officially announced its decision to allow men to live on campus as residential students, although most faculty and staff and some students knew of this decision earlier. Student responses to this decision varied widely, from those who were angry and wanted to remain a residential women's college, to students who welcomed men and saw this change as another aspect of the institution's diversity. This decision, although not entirely a surprise, combined with the election results to create a highly-charged atmosphere on campus. The admission of men onto the residential campus heightened fears for some women, particularly those who had been sexually assaulted and chose to attend a women's college because they saw it as a safe place. In addition, the increase in hate crimes that occurred after Trump's election, both on campus and farther afield ("Ten Days After"), influenced already-present concerns from students of color about their safety and sense of belonging in a rural, predominately white small town in the conservative Shenandoah Valley.

\section{Anthropology, Community Art, and Ethnographic Methods}

Like other course iterations, Permeable Borders 2017 ran for three weeks during Mary Baldwin University's May Term. The 2017 course, similarly, was structured primarily around creating the mural. The vast majority of course time, two weeks, was spent doing this work, which included working collaboratively to develop the mural design, applying gesso, sketching and painting, and applying the final sealer. This schedule allowed for only three days of pre-mural preparation, taught by the faculty instructors. Because previous murals had direct themes such as immigration, the border, and segregation - student-artists typically prepared for the mural and their work as community artists by developing knowledge around these themes. At Bernardi's request, however, we did not designate a theme for the 2017 mural, as she wanted that theme to emerge from the community, via the studentartists. Without a designated theme, the task of pre-mural preparation became developing student visions about the mural. This involved, of course, readings and discussions of Bernardi's previous artistic work, community murals, and political activism as well as a lecture by my co-instructor on the history of muralism.

As an anthropologist, I saw the mural as a way for student-artists to reflect upon and "make sense of" (DuBois 97: 7) our campus and broader community in the context of the uncertainty of the Trump era and the looming transition to a fully co-educational campus. As a result, my role during the pre-mural preparation was to help the student-artists develop themes for the mural that reflected not just the twenty MBU students in the course, but the broader Mary Baldwin University community. Since three days is obviously not nearly enough time to fully develop and deploy ethnographic methods, we experimented with two methodological approaches, Photovoice and interviews, while also relying on our student-aritsts' position as native anthropologists - members of the community that they are "studying" - as a way to "study" the Mary Baldwin University community.

As the first method, Photovoice provided an opportunity for the student-artists to begin a conversation about what they wanted the mural "to say." First developed as a participatory action research methodology in public health (Wang and Burris 1994), Photovoice has typically been used by researchers to elicit participant perspectives on their community, particularly on community issues and needs. As Wang and Burris wrote in their 
foundational article, Photovoice is intended to empower, educate, and inform policy (1994: 171-172). Although there is considerable variation, Photovoice is generally accomplished in several steps - participants document their community through photographs, collaboratively share analyze the photographs, and finally use the photographs and analyses in some way, often to generate policy changes - that we tried to implement, albeit in a much shorter timeframe, in Permeable Borders (Bell 2008: 38; Wang and Burris 1994: 171-172). Importantly, as Bell points out, Photovoice projects are often intended to reach out to those whose voices are not often heard; as a result, "it is often women, racial minorities, and people of lower-socioeconomic status that become the community-based documentary photographers of Photovoice" (Bell 2008: 38). In her Photovoice project in rural Appalachia, Bell found that Photovoice did indeed empower participants and had great potential for community organizing and building social capital (ibid.).

In the context of developing mural themes, Photovoice allowed our students to begin thinking of how to represent complex issues in semiotic rather than semantic form. We began by asking students to take four pictures on their smart phone that they felt represented something they wanted to include in the mural, something important about our community, and upload them with a few short sentences explaining what was significant about the photograph. The following day in class, we went through the photographs, discussed what we saw, and grouped the photographs into broad themes. Finally, we collaboratively developed interview questions from these themes and analyzed the data that these produced.

Some themes were fairly obvious and seemingly superficial. Students, for example, almost uniformly took a picture of somewhere on our campus, located on a steep hill above Staunton, to illustrate our beautiful location. In discussion, however, it became clear that Mary Baldwin's hills are polysemic and hold deeper meanings for students; they are more than simply beautiful. Students repeatedly discussed how the stairs and the hill were "hard," but also what made Mary Baldwin beautiful, a metaphor for the ways that many of our students perceived the challenges of their education: hard work, and sometimes daunting, but worthwhile. Students also routinely included pictures of their friends and discussed the friendships and relationships that they had built, often describing these in terms of fictive kin relations. Like the photographs of campus landscapes, pictures of friends are also more complex than they first appeared. Most pictures of friends were included specifically because their friends reflected the diverse Mary Baldwin student population, and students made constant reference to feeling safe (or perhaps safer than other local public spaces) due to the inclusive nature of the campus environment.

This experience of an inclusive campus was contrasted to a highly ambiguous commentary on Staunton and the broader community. Two photographs were particularly striking here - interestingly, two students, working independently, took the exact same photograph. Both photographs featured a building on the edge of downtown Staunton, a short walk from campus. On the bottom floor is a slightly disreputable pizza restaurant and bar. The upper stories of the building house apartments. One apartment window featured a gay pride rainbow flag. Above it and a few windows over, a Confederate battle flag was displayed. See Figure A for an example of one of these photographs.

As the student-artist wrote in her assignment submission, "The two juxtaposing ideas being displayed by these flags just outside of campus represents to me the paradox that is the population of Staunton and Mary Baldwin University." Figure B, below, represents another version of this sentiment:“this picture is from pride week. I'm so glad this campus makes a strong effort to be inclusive and informative, spreading positivity amongst so much turmoil. I hope the school continues to push a message of togetherness and acceptance." Again, we see in both photographs and discourse, a tendency for students to see their campus community as an inclusive environment, quite different from the perceived intolerance outside of campus. In class discussion, of course, student-artists universally acknowledged that campus was far from a perfectly inclusive environment and that much work remained to be done. In comparison to "off campus," however - in this context, Staunton and the broader region - students held steadfast to their beliefs that the MBU campus community was much more tolerant and welcoming that the surrounding community. It should be noted, however, that these student perceptions do not necessarily reflect the political and social realities of the city of Staunton. Although the broader Augusta County community is overwhelmingly conservative, the city itself tends to narrowly support progressive Democratic candidates in local, state, and national elections. Importantly, the city also conceives itself, in many ways, as open and tolerant - particularly in comparison to Augusta County. 


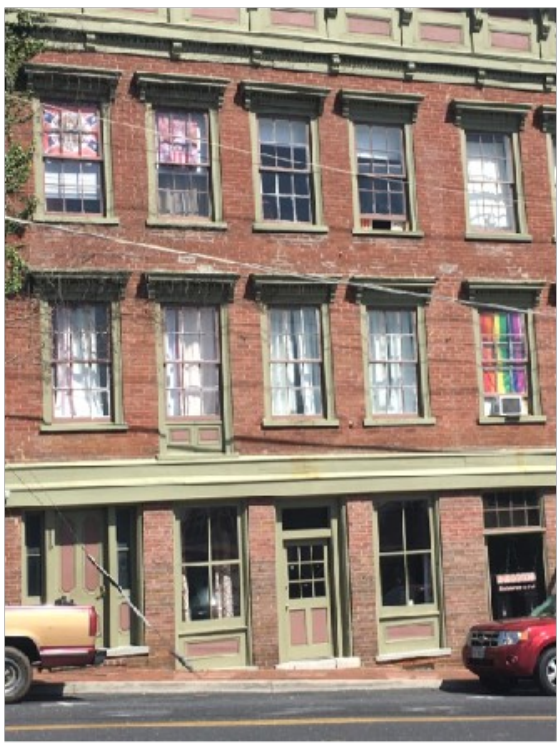

Figure A. Contradictory window flags, a rainbow flag in the middle right and a Confederate battle flag in the upper left. Photo by student.

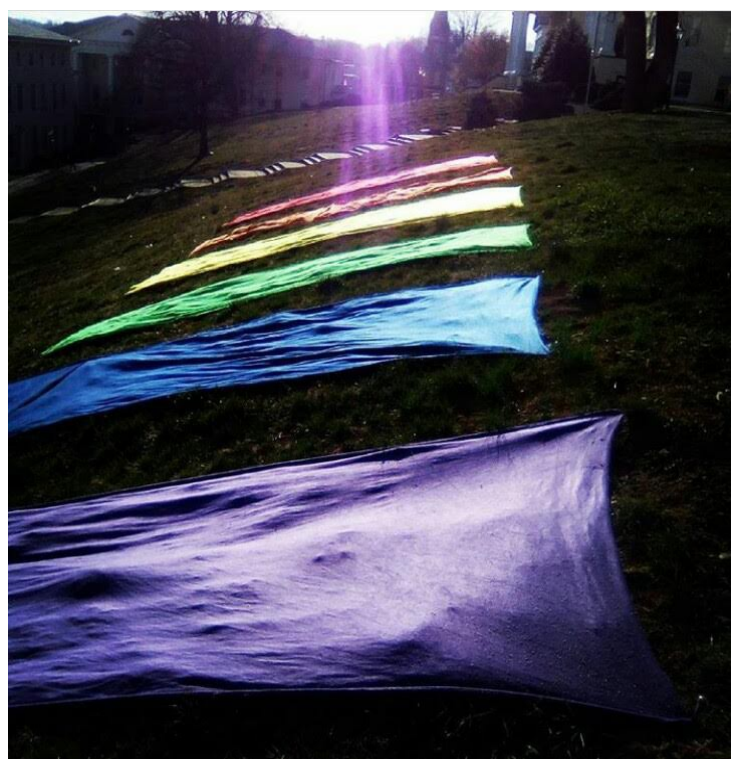

Figure B. Rainbow flags displayed prominently on the Mary Baldwin University campus for National Coming-Out Week. Photo by student.

From the photographs, the student-artists identified common themes and issues and from these, collaboratively developed a short set of four interview questions, listed below.

1. What do you find beautiful about our campus? About Staunton?

2. What do you find challenging about living on our campus? About living in Staunton?

3. What has changed for you living on our campus? About living in Staunton?

4. What do you think we should put on our mural?

Each student-artist then interviewed three "members of the Mary Baldwin University community," which we left intentionally broad. Student-artists submitted the transcriptions of their interviews and the results were analyzed collaboratively in class.

Because the interview questions were drawn from the photographs, there was broad correspondance between some aspects of the interview results and the photographs. Interview respondants generally focused on the physical beauty of campus, such as the mountains, trees, flowers, and the hills of Staunton and the Shenandoah Valley. Respondants also strongly desired this physical space to be represented on the mural - in particular, mountains, flowers, and trees, even more so than buildings or other recognizable built features of campus. Like our students-artists, respondants recognized the mobility challenges of living on campus and getting off of it; a constant theme was the lack of efficient public transportation around Staunton.

Unsurprisingly, respondants also emphasized the inclusion and diversity of our student population. Many respondants unequivocably indentified this element as something that should be represented on the mural. One respondent, for example, was quoted as saying, "the most beautiful thing about our campus is our students, because we have students from all over the country and all over the world and I think that we come together in such a harmonious way. This is the only place I've ever experienced where there is such diversity in the student body." Like our student-artists, respondents tended to contrast campus diversity with that of Staunton and the broader community, but the interviews elaborated on this point in ways that our photographs and course discussion did not. Respondants frequently commented that while they felt included and "safe" on campus, they did not feel safe in Staunton. One respondant said that she avoided showing physical affection to her girlfriend in Staunton, because she did not feel comfortable doing so in such a "conservative" environment. Another respondant said that the "outside community" is "scary and intimidating." Similarly, a respondant stated that "living in Staunton I have learned to be ten times more aware of my surroundings because there tends to be at least some scary situation in Staunton." Several respondants directly connected feeling less secure with "the recent political situation," and several additional respondants suggested that specific political issues and events should be included on the mural. 
The concerns about safety, and feeling unsafe, are particularly illuminating, since many residential students are coming from larger urban areas in Northern Virginia, Washington DC, and Richmond. In fact, many of the interview respondents commented directly on this; one said that, "I'm from a city, so going from a big city to a really tiny town is difficult. It's a culture shock" and another said that living in Staunton has made her realize that she prefers living in big cities because there is more diversity. Some respondents, however, described Staunton as being small but "friendly" and having a "cool, artsy vibe" downtown. These responses suggest that, at least for some students, the welcoming sense of inclusion and diversity they experience on campus is lacking - or perceived to be lacking - off campus. As a result, they often report feeling insecure, uncomfortable being themselves, or unsafe, despite living in a small town with small town crime statistics.

These two methodologies, Photovoice and interviews, allowed the students-artists to engage in community work like a native anthropologist, encouraging them to pay close attention to their community while also allowing for other community perspectives and requiring collaboration to develop themes and issues. Simultaneously, this process also gave the student-artists agency, as artists, to determine the content of the mural. The photographs, interviews, and ensuing class discussions prepared them for their first course meeting with Claudia Bernardi and the work of making interviews, conversations, and discussions into visual images for the mural itself.

\section{The Mural}

After three days of classroom work on developing mural themes, the course shifted towards creation of the mural. As a traveling mural, the canvas was stretched on a large purpose-built wooden frame. We created the mural on a wide, open mezzanine in the main dining hall on campus, a location that was intentionally visible to all of the students, faculty, and staff who frequent the building. Sitting in a wide circle in the empty dining hall, Bernardi led the student-artists through a series of conversations that included introductions, some background on her process of making murals, and a discussion of possible mural themes. Using their "data" from the Photovoice and interview projects, student-artists volunteered several elements they would like to see on the mural: mountains, the beautiful campus, diversity and inclusion, and the major issues of our recent political situation: Black Lives Matter, increasing deportation of undocumented people, and the Women's March.

From this collective discussion, Bernardi asked the student-artists to begin sketching their ideas with pencil and paper. After some preparation of the mural - measuring and taping off a border and putting a color "wash" over the blank canvas - the student-artists began to consider how their individual drawings might contribute to the larger "story" or theme of the mural. At this point, we began taping drawings to the canvas to better see the development of the mural. As the mural further developed, it became essential to have careful conversations about mural content. Bernardi guided these discussions, but required that the student-artists work together to come to, as she put it, "consensus." For Bernardi, consensus means that some (though not necessarily all) student-artists who did not agree on a particular issue on the mural would become a "committee" to work through the problem via discussion. The resulting solution was one derived by conversation and debate, but Bernardi expected that all would be in agreement.

Bernardi's "committee and consensus" process is best illustrated with a particular example. One issue that emerged early in the mural creation was how to orient the mural story on the canvas. Although the studentartists universally agreed that they wanted the mural to show temporal movement - in Bernardi's words, to have a past, present, and future - they struggled to come to consensus over how time should be visualized on the canvas. Bernardi gave them two options: the past on the right or the past on the left. She clarified that for most Western people, the past is visualized as being on the left side and moving right. One student-artist, a Saudi Arabian international student, pointed out that for him, the past begins on the right and moves left, because that is the direction that Arabic is read. Several student-artists liked the idea of using a "non-Western" temporal scheme and argued persuasively for the past beginning on the right. Although it appeared that consensus was reached over this issue, and the mural does indeed begin with the past on the right, responses in their end-ofclass response papers illuminated that some student-artists felt left out of the conversation, preferred the past starting on the left, and were frustrated with the "consensus" process since it did not include everyone.

Although Bernardi is a visual artist, she often begins the mural process by clarifying that she does not "touch" the mural at all. As should be clear from the above example, however, Bernardi does guide some decisions, both thematic and artistic. She often does so by presenting several solutions to a "problem" that the mural presents, such as where or what to put in a particular spot on the canvas. There was, in fact, only one student-artist who was a studio art major; the rest of the student-artists and other participants had very little artistic training, if any. 
Despite this, the mural was not difficult to paint; the most challenging components were deciding on the mural themes and content, as well as coming to consensus when disagreement occurred. The remaining time in the course, after the major themes and images were decided - about two weeks - was spent painting the mural. See Figure $\mathrm{C}$ for a composite image of the entire, completed mural.

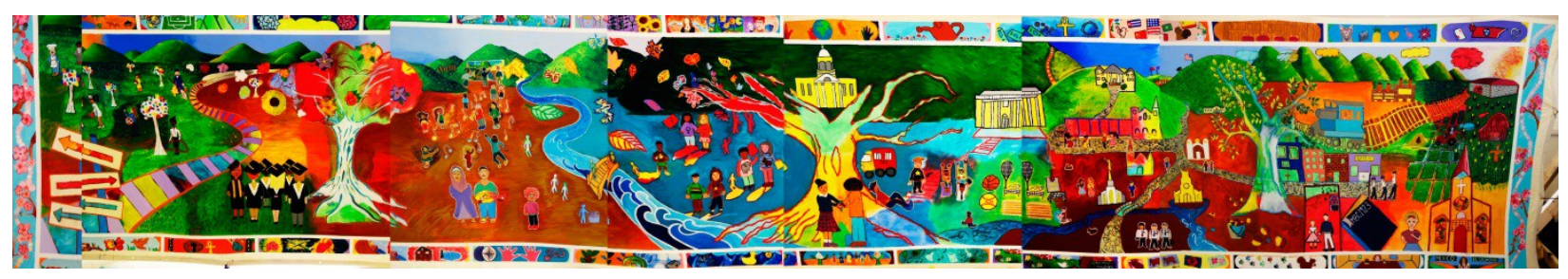

Figure C: a composite of the completed mural. Photo by Debbie Koppman.

The past, beginning on the right, depicts the mountains and agricultural scenes of the historic Shenandoah Valley, including a tractor bulldozing a Native American mound, a common practice. Some scenes of downtown Staunton and Mary Baldwin, with figures clearly in historic clothing, index the past. Churches, a synagogue, and a mosque are also scattered over the right side of the mural. The future, on the left, includes scenes of graduation - an image that the student-artists uniformly wanted on the canvas, to represent their goals and purpose, as well as a set of three road signs that symbolize the different paths that the future may hold for each student. A train, winding through the painted hills and mountains, connects the past to the future. Around the edge of the canvas, the border was divided into uniform rectangles that each student-artist painted with images that were important to them, ranging from politics to religion to hobbies.

The center is the largest and most compelling piece of the mural. The exact center of the mural is taken up by a large tree, mountains, and recognizable and central campus buildings (the library and main dining hall). In the lower foreground, above the roots of the tree, two figures face each other, holding hands. Slightly to the right, in the past, an image includes four students with their arms up in the air, facing an armed police officer. Close to the officer, a truck with a clear ICE label depicts the deportation of undocumented people. These last two images, overtly political, were painted by two specific student-artists who wanted these issues represented. Despite their potential for controversy, I am not aware of any dialogue or concern about their presence on the mural. The image of the police officer and students, however, did have to be painted twice, as it was painted over - although it is unclear whether or not this was intentional.

\section{Analysis: Convivio}

Both the process of mural creation and the mural itself offer interesting insights into the perspectives of contemporary college students in the US in the Trump era. Images and representations "engage in emotional and political work, producing sympathy and empathy, as well as fear and othering" (Holmes and Castaneda 2016: 17). These feelings and orientations, however, are not uniform and may be interpreted differently. During the creation of the mural, many student-artists and faculty discussed this issue frequently. While some images have fairly unambiguous meanings, many are more subtle. Additionally, as noted, student-artists did not always agree with each other on the meanings of particular images. Although I did my best to incorporate the intentions and perspectives of the student-artists, my analysis reflects my own interpretations. "Convivio," I suggest, reveals general MBU student anxieties and reactions to pressing political events. It also, however, serves as a territorial marker of an idealized MBU identity that is inherently critical of the Trump administration's policies, and is framed in stark opposition to them.

Several mural images clearly reflect both "ordinary" and extraordinary student anxieties. Like most college students, our student-artists had fairly typical concerns about the future and their place in it. This is particularly evident in the image of students graduating, on the left or future side of the mural, as well as the final image - a signpost with arrows pointing different directions, indicating many paths forward, the many futures for the student-artists. These were images that the student-artists were very adamant about including on the mural, because as one student-artist stated, "this is why we're here - to get an education, to graduate." Although these images may seem apolitical, I would suggest that given the average student loan burden for American 
undergraduates, graduation and visible (and multiple) career paths are in fact subtle political statements about claiming a successful future despite the steep cost and public criticisms of the "value" of a liberal arts education.

In addition to these familiar concerns, however, are the overtly political images such as the ICE van and the image of a police officer pointing a gun at people of color. Importantly, the student-artist intended this image to be a police officer pointing his gun at students. As the student-artist stated, the people on the mural were "just college kids trying to get an education." This image presents a striking contrast to the image of graduating students discussed in the above paragraph. Racism, here embodied in the police officer, was perceived and articulated as a barrier to education, and therefore, to success. Although racism and deportations are not new, our student-artists associated these problems - and meant these images - to represent heightened anxieties about life in the Trump era.

Although student anxieties are clearly expressed, the mural has arguably more "to say" about how students feel about Mary Baldwin University and their diverse community. The most prominent image in the mural is the center: two individuals (gender unspecified, one dressed in a dress, one in pants), clearly from different racial backgrounds. This image, which links racially different, gender ambiguous individuals together in peace and friendship, is clearly tied to Mary Baldwin: the two individuals embrace at the root of a large tree, its trunk leading path-like up to a building clearly recognizable from its distinctive cupola as Hunt Dining Hall, itself Mary Baldwin University's most familiar building. As it sits in the exact center of the mural, the image represents the contemporary, the now, the current moment - from the perspective of the student-artists. This is their depiction of Mary Baldwin University in 2017. It is place where people of different backgrounds come together, a place of diversity and tolerance.

This intentional coming together, the process of being together despite or because of different and even fraught backgrounds, is what Bernardi describes as convivio. A common translation is often rendered as coexisting or coexistence, but as Bernardi has pointed out, in El Salvador convivio has a particularly specific meaning of choosing to be together, rather than merely existing in spite of and with little concern or care about difference (Bernardi 2017). Bernardi's usage makes coming together despite difference not just an intentional act, but a political one. It was a term she used occasionally during the May Term course, and several student-artists heard it, liked Bernardi's definition, and suggested it be the mural title.

Convivio, as a concept embraced by the Permeable Borders student-artists, and "Convivio," the mural, firmly situate contemporary Mary Baldwin University as a place of tolerance, where differences exist but do not divide. This is a contrast, at least from the perspective of some Mary Baldwin students, from the external, off-campus communities of Staunton, the Shenandoah Valley, and central Virginia. It is also a perspective that was evidenced in most, although certainly not all, Photovoice and interview submissions. It is also, of course, an idealized representation. While there is some truth to the diversity and tolerance of Mary Baldwin campus life, the romanticized images of the university as having moved beyond the divisiveness of race and religion, as being a place of tolerance unique in our community, often contradicts with the realities of life on campus.

As Jack Santino has noted in Northern Ireland, murals are a kind of "marked culturescape" that serve multiple purposes, including marking the boundary of a particular neighborhood. He notes that

The frequency of public symbolic display is due in part to the ongoing need for such displays in a context of contestation. In such a context, symbols are not merely displayed or enacted, they are used: to assert territoriality and identity, to welcome or warn, and frequently, to offend. It is often observed that flags are more likely to be displayed in areas where there are significant numbers of a population who will be offended by their presence... [1999: 520].

While Santino studied murals in place - on walls and buildings, for example, where the territorial function is more obvious - "Convivio" can be seen as a kind of territory marker. Although the mural can be moved and displayed in various locations, the student-artists knew while they were creating it that it would be prominently displayed on the main floor of the university library. In this context, the images take on a more significant value as a highly visible marker of Mary Baldwin identity and values: both for currents students, faculty, and staff, but also to visiting community members and prospective students. Even though it may be idealized, its inclusiveness is also aspirational and oppositional, distinctly different from the philosophies of the Trump administration.

As a result, "Convivio" should be understood as a specific and intentional statement about diversity and tolerance created in May 2017, roughly six months after the election of Donald Trump as president of the United 
States. At Mary Baldwin, many students perceive themselves to be part of a unique community of difference and tolerance, surrounded by a perceived sea of intolerance in Staunton and Augusta County. This demographic situation, combined with the xenophobic and anti-diversity rhetoric of the Trump administration ("Trump's Battle Against Diversity"), provided the cultural context of the creation of "Convivio." While the mural itself portrays a tolerant present - at MBU, at least - and a hopeful future, it was created in a "context of contestation," when tolerance itself was and continues to be contested. Similarly, in its prominent perch in Grafton library, "Convivio" vividly asserts that Mary Baldwin is a place of diversity, tolerance, and, of course, convivio.

\section{Conclusion}

As a course and as a collaborative art project, "Permeable Borders" presented the faculty and student-artists with plenty of challenges. As an instructor, the most significant challenge was adequately incorporating anthropology into the course. During the three week span of the class, the majority of our class time was necessarily devoted to the creation of the mural. There was simply not enough time allotted to the beginning of the course to allow for a more thorough introduction to anthropological concepts and methods. This is partially due to circumstances beyond our control - the university calendar, for example - but is also connected to the structure of the course. Creating such a large mural requires a significant amount of time. For Bernardi, this course is primarily about the collaborative creation of art, so from her perspective, course time was allotted appropriately. In addition, however, disciplinary differences between art and anthropology suggest different methodologies, particularly in terms of how the mural themes were developed. As an anthropologist, I wanted the student-artists to be more systematic, ethnographic, and inclusive, whereas Bernardi, an artist, tended to privilege the feelings and intuition of our student-artists over other Mary Baldwin University students not working on the mural. This tension was not entirely relieved throughout the creative process, as Bernardi did not include or reference the pre-mural ethnographic data when she worked with the student-artists to develop the mural themes. Future interdisciplinary work clearly requires more thoughtful and intentional discussions of how to incorporate multiple disciplines within the limits of this project.

Despite these challenges, the Permeable Borders course was successful in multiple ways. Pedagogically, the course illustrated the value of Photovoice beyond its typical use as a participatory research method. As evidenced in Permeable Borders, Photovoice can also be successfully used as a teaching pedagogy. Because students are very familiar with taking pictures on their smart phones, Photovoice can be an engaging way to introduce students to "data collection," as we did here, or of using Photovoice to illustrate a course concept through student-produced visual "data" in the form of photographs. In addition, I expanded upon the traditional "community needs" usage of Photovoice. As Hall (2017) has noted, using Photovoice to document community deficits or problems can support or reinforce existing deficit-thinking in marginalized communities. Asking students to visually document "important" aspects of Mary Baldwin University life in 2017 - as defined by the student-artists - allowed the photographs to reflect both strengths and assets, as Hall suggests (ibid.), as well as problems and concerns.

Both Photovoice and the interviews required the student-artists to learn experientially, by actively engaging with multiple communities. The resulting data provided an opportunity to see and collaboratively analyze qualitative data, a process that allowed for the data to interpreted from multiple voices and perspectives. Although these methods and the data they produced were not directly incorporated into Bernardi's mural process, student-artists drew upon this work as they developed mural themes. As a result, data are clearly reflected in the images of "Convivio" and therefore were an important component in the creation of the mural.

As a collaborative art project, the mural was another successful manifestion of Bernardi's Perquin Model, here with a particular emphasis on the concept of convivio. The resulting mural is both beautiful and resonant, and the student-artists were justifiably proud of their efforts. "Convivio" is also a deeply meaningful and symbolic visual statement in the Trump era, an idealized but still powerful territorial marker that defines Mary Baldwin's identity as diverse and tolerant. 


\section{References}

Bell, Shannon Elizabeth (2008), 'Photovoice as a Strategy for Community Organizing in the Central Appalachian Coalfields,' Journal of Appalachian Studies. 14(1/2): 34-48.

Bernardi, Claudia (2010), 'Art, Memory, and Diplomacy: A Possible Model for Community Building,' Beliefs and Values. 2(1): 80-89.

-- (2017), 'Fall Lecture: Convivio,' Mary Baldwin University. Presented October 5 2017, Staunton, Virginia.

Bloomberg Politics 9/8/17, “Trump’s Battle Against Diversity,” Retrieved January 102018 from:

https://www.bloomberg.com/news/articles/2017-08-09/trump-s-anti-diversity-stance-rallies-culture-warriors-

$\underline{\text { in-u-S }}$

Chronicle of Higher Education 13/12/2016, "Here's A Rundown of the Latest Campus-Climate Incidents Since Trumps Election," Retrieved 10 January 2018 from: https://www.chronicle.com/blogs/ticker/heres-arundown-of-the-latest-campus-climate-incidents-since-trumps-election/115553

DuBois, Lindsey (1997), 'Past, Place, and Paint: A Neighbourhood Mural Project in Suburban Buenos Aires,' Anthropologica. 39(1/2): 7-15.

Hall, Amanda (2017), 'We Are...': Dismantling Deficit Thinking Through Photovoice as Critical Service Learning,' IARSCLSE Annual Conference. Presented September 14, 2017, Galway, Ireland.

Holmes, Seth M. and Heide Castaneda (2016), 'Representing the European Refugee Crisis in Germany and Beyond: Deservingness and Difference, Life and Death,' American Ethnologist. 43(1): 12-24.

Santino, Jack (1999), 'Public Protest and Popular Style: Resistance from the Right in Northern Ireland and South Boston,' American Anthropologist. 101(3): 515-528.

Southern Poverty Law Center 29/11/16, "Ten Days After: Harassment and Intimidation in the Aftermath of the election," Retrieved 10 January 2018 from: https://www.splcenter.org/20161129/ten-days-after-harassmentand-intimidation-aftermath-election

Southern Poverty Law Center 26/12/16, "Update: 1, 094 Bias Related Incidents in the Month Following the Election," Retrieved 10 January 2018, from: https://www.splcenter.org/hatewatch/2016/12/16/update-1094bias-related-incidents-month-following-election

Wang, Caroline and Mary Ann Burris (1994), 'Empowerment through Photo Novella: Portraits of Participation,' Health Education Quarterly. 21(2): 171-186. 